\title{
Anthrovision
}

Vaneasa Online Journal

Vol. $7.1 \mid 2019$

Aesthetic Encounters

\section{Introduction: Politics of Moving and (Un)settling Visual Arts}

\section{Thomas Fillitz}

\section{(2) OpenEdition \\ 1 Journals}

\section{Electronic version}

URL: http://journals.openedition.org/anthrovision/4344

DOI: 10.4000/anthrovision.4344

ISSN: 2198-6754

\section{Publisher}

VANEASA - Visual Anthropology Network of European Association of Social Anthropologists

\section{Electronic reference}

Thomas Fillitz, «Introduction: Politics of Moving and (Un)settling Visual Arts », Anthrovision [Online], Vol. 7.1 | 2019, Online since 31 December 2019, connection on 13 November 2020. URL : http:// journals.openedition.org/anthrovision/4344; DOI : https://doi.org/10.4000/anthrovision.4344

This text was automatically generated on 13 November 2020 .

(c) Anthrovision 


\title{
Introduction: Politics of Moving and (Un)settling Visual Arts
}

\author{
Thomas Fillitz
}

Short versions of the following articles were presented at the panel 'Aesthetic Encounters: The Politics of Moving and (Un)settling Visual Arts, Design and Literature,' which Paula Uimonen (Stockholm University) and I organized at the fifteenth biennial conference of the European Association of Social Anthropologists in Stockholm 2018. The panel's success, however, is also largely due to Helena Wulff, who provided invaluable ideas for its conceptualization, for which I wish to express my gratitude. We proposed to participants to think about anthropology's interactions with visual arts, literature, film, and design within the framework of the multiple meanings these arts have now acquired with their unprecedented circulation and reception at a global scale. At the EASA panel, Paula Uimonen and Helena Wulff presented topics from the field of world literature. Sadly, neither could contribute to this issue of Anthrovision.

Until the late 1980s and early 1990s the field of visual arts was centred on the hegemony of occidental art history - its determination of dominant formal canons and of the category modern art. Movements of art works were either concentrated within the Western European and North American national art worlds system, or artists from other regions of the world were tempted to become incorporated within it, or this specific art world appropriated art from other regions according its own discretion. In the anthropology of art, this was the time of the most powerful The Traffic in Art and Culture by George Marcus and Fred Myers (1995), in which they claim as the objective of their 'critical anthropology of art': to investigate 'the art world's manner of assimilating, incorporating, or making its own cross-cultural difference' (Marcus and Myers 1995: 33).

By the new millennium this system was supplanted. European and North American art specialists became aware of the geospatial diversity of contemporary art, and occidental art history lost its hegemonic functions. Artistic practices, cultural institutions, art discourses, even market institutions, articulated locally and regionally specific types of knowledge and experiences (see Enwezor 2002; Belting 2013; Fillitz 
2018). As a consequence, contemporary art is defined in how it is local, regional and global (Smith 2013: 188). This neither relates to a style or an art medium. Art is contemporary as it articulates the artist's preoccupations of the contemporary world, that is its insertion within society (e.g. Smith 2011; García Canclini 2014). Multitude as geographical expansion, and multitude regarding the category of art, are two characteristics of contemporary art in a global perspective.

4 Another important category is movement, closely connected to the new dominant exhibition form, the biennial. ${ }^{1}$ Indeed, there has been a colossal global proliferation of art biennials from the mid-1990s on. These mega-art institutions are the new authorities for defining contemporary art, as Charles Green and Anthony Gardner (2016) argue (see also Altshuler 2013). As they do not hold art collections (like museums), these cultural institutions are in need of contemporary art, of artists, curators, and art specialists: for each one according to its cycle (biennial, triennial, etc.), and for all biennials on a global scale. Within the network of biennials, the movement of visual arts is multi-directional, even if most renowned curators, artists, and art specialists select their routes in relation to the most powerful cultural institutions.

Under constellations of the contemporary world, that is interconnected multiple worlds (cf. Augé 1994), movement is indeed co-constitutive of contemporary art regarding social agents (artists, curators, art specialists), art's media, techniques (artistic and curatorial), or knowledges (art histories, socio-cultural), and regarding geospatial scales (local, regional, transnational, or global).

6 Two major research topics structure the papers of the special issue 'Politics of moving and (un)settling visual arts': first the contrast between the regional particularism of contemporary art and the creation of a global canon of contemporary art; second, art's insertion into society as reconceptualization of its role, against another 'arbitrary canon' (García Canclini 2014: 175) that is socially embedded works and processes (García Canclini 2014: 175).

7 Firstly, while contemporary art is acknowledged as a highly heterogeneous and diverse category, there is nonetheless a global art discourse which is closely related to the formation of another global art canon - installation and relational art. For John Clark (2010), the preponderance of art biennials on a global scale leads to the production of 'the canonical works of contemporary art' (Clark 2010: 165), and thereby influence artistic practices in local and regional art worlds. The canonization of art is the topic of Tamara Schild and Thomas Fillitz. Schild examines internationally operating art market institutions and the sales interests of leading auction houses. To these ends, their construction of an art canon follows the production of a new category of potential buyers. Fillitz reflects on the impact of art selected for the official exhibition of the Biennale of Dakar on artistic practices in the Dakar art world.

8 Schild studies the global market field of auction houses since the 1980s, and its production of a universal art canon for traditional African and Oceanic art. Schild argues that this particular present-day universal canon is historically connected to the importance of these artworks for European modernist artists of the early twentieth century. Further, the author views its elaboration due to new profiles of the auction house curators, of changing strategies in the production of the catalogues, and the active creation of so-called cross-over collectors. 
9 Based on his research of the Biennale of Dakar, Fillitz reflects on the notion of 'biennial art,' another circumscription for the global canon of contemporary art as displayed at leading biennial exhibitions - installation art, and artworks which express social aspirations. Biennial art, moreover, emphasizes that this art would strongly influence local and regional artistic practices. In innumerable independent exhibitions during the Biennale, however, artists largely show paintings. Fillitz argues that economic reasons cannot help to explain this preponderance. Instead one needs to look at the history of modern and contemporary art in Senegal. Broadening the perspective, one may question the assumption of a global art field in the singular, that is a conceptualization of contemporary art which is globally validated by a few curators and such art institutions.

The second topic of this special issue, the reconceptualization of the role of art,, relates to García Canclini's (2014) hypothesis of art as the place of imminence, 'the place where we catch sight of things that are just at the point of occurring' (García Canclini 2014: xiii). García Canclini conceives of imminence as a tool to experience other possibilities for social life (2014: 168). The two articles by Alex Flynn and Lucy Bell, and by Paolo Favero, relate to different notions of 'embedded art,', and thus on different practices of creating imminence. Flynn and Bell examine cartonera publishers, and describe how critical work is produced and shifts into various social relations that enable an activation of social criticism. Favero focuses on a fundamental visual question: the picture and digital processes of its making. He elaborates on the newest techniques, which encourage reflection on the fundamental conditions of the encounter with pictures, and which enable to trespass boundaries, such the ones between artist and beholder. Furthermore, the two articles operate with other closely related concepts. Flynn and Bell may be related to decoloniality, that is knowledge production on the basis of relational, multiple voices, and a combination of analysis and praxis of knowing and living (see Mignolo and Walsh 2018). Favero speaks of 'decolonizing knowledge,' by introducing into his description of technological innovations of image-making categories from other (spatio-temporal) visualities, and epistemologies.

11 Alex Flynn and Lucy Bell's starting point is art's insertion into society, one of the major criteria of the global canons of contemporary art. Flynn and Bell ask about knowledge production through collaboration. During their ethnographic fieldwork with cartonera publishers in Latin America, they had to reflect on the collaborative possibilities between researcher, these publishers, and the various fields these latter activate in their creative processes, not only for data collecting but for active participation. Cartonera publishers are small collectives that produce small, low-cost books from recuperated waste cardboard in close interaction with local neighbourhoods. For Flynn and Bell, cartoneras challenge ethnographic research insofar as they are art projects which are at the same time social activism..The authors thus aim to formulate a methodological approach that corresponds to these processes of the cartonera publishers, within which social and aesthetic forms are indivisible. Relying on the cartoneras' activation of four forms - exhibitions, workshops, co-editions, and encontros (meeting, gathering, networking) - Flynn and Bell articulate a trans-formal approach which would allow to move analytically across different forms (aesthetic, social, political, etc.), and thereby postulate the emulation of the forms of cartonera publishers as a fundamental method of ethnographic fieldwork. 

He focuses on the newest technologies of image-based immersive practices. These enable practitioners to question the hitherto 'taken for granted' divides of picture theories, such as the ones between viewer and viewed and between self and the world, by including beholders to actively participate in these reflexive processes. Even so, Favero demonstrates that these new technologies and practices contain traces of visual conceptualizations from other times and regions - such as Byzantine icons, or Hindu popular religious art. Pushing this insight further, Favero thus proposes the investigation of the 'act of decolonization of knowledge' as another visual research field, i.e. to examine newest contemporary arts and documentary practices by means of trans-regionally and trans-disciplinary categories and concepts of various types of images.

13 In his epilogue, Jonas Tinius connects the four articles on two distinct analytical trajectories: for Schild and Fillitz,'institutions, histories, and spheres of valuation'; and for Flynn/Bell and Favero, 'immersion, correspondence, and form.' On this basis, Tinius pushes the reflection further, and argues for an 'attuned anthropology of the contemporary'. This has as research topic the tensions between art and aesthetics that are created through their interplay at different levels of the local, regional, transnational, and global. In a related way, Tinius highlights the benefits of an 'anachronistic and anatopical positionality and approach'. He then connects the overall topic of these contributions to his conceptualization of a recalibrated, anachronistic and anatopical anthropology of the contemporary, insofar as the art related processes in the different fields 'become tools of our own analysis'.

methodological issue is explicitly approached by Flynn and Bell. Indeed, the challenge to the contributors of this collection was to reflect power relations (politics of moving) and artistic preoccupations or, in other terms, the contemporaneity of art as a contrast between the given social hierarchies and pictures of desires or alternatives for life. All contributions invite a further envisioning of the active role of anthropological research and representation in the field of art, not only as a mediator. Confronting the economic power of market segments, or the cultural power of art institutions, whether more or less 'embedded,' artistic practices encourage us to rethink and debate conditions of life, and anthropological research on art may contribute with its critical discourses, as proposed for instance by Favero using the concept of 'decolonizing knowledge.'

\section{BIBLIOGRAPHY}

Altshuler, Bruce, ed. 2013. Biennials and Beyond - Exhibitions That Made Art History. 1962-2002. London and New York: Phaidon Press.

Augé, Marc. 1994. Pour une anthropologie de la surmodernité. Paris: Aubier-Critiques. 
Belting, Hans. 2013. The Plurality of Art Words and the New Museum. In The Global Contemporary and the Rise of New Art Worlds. Hans Belting, Andrea Buddensieg, and Peter Weibel, eds. Pp. 246-254. Cambridge, Mass. and Karlsruhe: The MIT Press and ZKM/Center for Art and Media.

Clark, John. 2010. Biennials as Structures for the Writing of Art History: The Asian Perspective. In The Biennial Reader Elena Filipovic, Marieke van Hal, Solveig Øvstebø, eds. Pp. 164-183. Bergen and Ostfildern: Bergen Kunsthall and Hatje Cantz.

Enwezor, Okwui. 2002. Großausstellungen und die Antinomien einer transnationalen globalen Form. Berliner Thyssen-Vorlesung zur Ikonologie der Gegenwart 1. München: Verlag Wilhelm Fink

Fillitz, Thomas. 2018. Concepts of "Art World" and the Particularity of the Biennale of Dakar. In An Anthropology of Contemporary Art. Practices, Markets, and Collectors. Thomas Fillitz and Paul van der Grijp, eds. Pp. 87-101. London et al.: Bloomsbury Academic.

García Canclini, Néstor. 2014. Art Beyond Itself. Anthropology for Society Without a Storyline. Durham and London: Duke University Press.

Green, Charles and Anthony Gardner. 2016. Biennials, Triennials, and documenta. The Exhibitions that Created Contemporary Art. Malden, MA. and Oxford: Wiley Blackwell.

Marcus, George E. and Fred R. Myers. 1995. The Traffic in Art and Culture: An Introduction. In The Traffic in Art and Culture. Refiguring Art and Anthropology. George E. Marcus and Fred R. Myers, eds. Pp. 1-51. Berkeley, Los Angeles, London: University of California Press.

Mignolo, Walter D. and Catherine D. Walsh. 2018. On Deoloniality. Concepts, Analytics, Praxis. Durham and London: Duke University Press.

Smith, Terry. 2011. Contemporary Art-World Currents. London: Lawrence King Publishing.

Smith, Terry. 2013. Contemporary Art: World Currents in Transition Beyond Globalization. In The Global Contemporary and the Rise of New Art Worlds. Hans Belting, Andrea Buddensieg, and Peter Weibel, eds. Pp. 186-192. Cambridge, Mass. and Karlsruhe: The MIT Press and ZKM/Center for Art and Media.

\section{NOTES}

1. I am using 'biennial' as term for the overall exhibition form, independently whether it is a biennial, triennial, follows a five year cycle as documenta, or other.

\section{AUTHOR}

\section{THOMAS FILLITZ}

University of Vienna

thomas.fillitz@unvie.ac.at 